\title{
Biosorption of lead by the brown seaweed Sargassum filipendula - batch and continuous pilot studies
}

\author{
Denise Mesquita Vieira \\ Universidade Federal do Rio de Janeiro \\ Escola de Química \\ Departamento de Engenharia Bioquímica \\ Ilha do Fundão \\ Rio de Janeiro, Brasil \\ Tel: 552125627621 \\ Fax: 552125627567 \\ E-mail: denisemvieira@yahoo.com.br
Antonio Carlos Augusto da Costa
Universidade do Estado do Rio de Janeiro Instituto de Química \\ Cristiane Assumpção Henriques \\ Universidade do Estado do Rio de Janeiro \\ Instituto de Química \\ Programa de Pós-Graduação em Engenharia Química \\ R. São Francisco Xavier 524, Sala 426 \\ Rio de Janeiro, Brasil \\ Fax: 552125877227 \\ E-mail: cah@uerj.br \\ Vicelma Luiz Cardoso \\ Universidade Federal de Uberlândia \\ Departamento de Engenharia Química \\ Av. João Naves de Ávila 2121 \\ Uberlândia, Minas Gerais, Brasil \\ Fax: 553432394189 \\ E-mail: vicelma@ufu.br
Francisca Pessôa de França*
Universidade Federal do Rio de Janeiro Escola de Química
Departamento de Engenharia Bioquímica Ilha do Fundão
Rio de Janeiro, Brasil
Tel: 552125627621
Fax: 552125627567
E-mail: fpfranca@eq.ufrj.br

Keywords: biosorption, biosorption equilibrium, continuous system, lead, Sargassum filipendula.

The biosorption of lead by the brown alga Sargassum filipendula was studied. pH 4.0 was the optimum value for the biosorption of lead. Isotherms indicated that for solutions containing $0.03 \pm 0.001$ up to $3.27 \pm 0.04$ $\mathrm{mmol} / \mathrm{L}$ of lead, $2.0 \mathrm{~g} / \mathrm{L}$ was the optimum biomass concentration. The
Langmuir model was fitted to represent the experimental data, and the kinetics of biosorption presented equilibrium in $30 \mathrm{~min}$. The continuous system operated for $56 \mathrm{hrs}$ presenting a $\mathbf{1 0 0 \%}$ binding of ionic lead, which corresponds to an accumulation of $168 \mathrm{~g}$ lead, equivalent to a load of $1.7 \mathrm{mmol}$

*Corresponding author 
ionic lead/g Sargassum filipendula. The results that were obtained in a continuous system showed a gradual saturation of the biomass in the reactors.

Industries that work with car batteries, sheets of semifinished metal, additives in gasoline, ammunition and scrap iron from car batteries are the main sources of effluents containing lead. Besides respiratory problems, lead provokes alterations in blood and urinary system.

Sargassum sp. is a brown seaweed typically found in tropical countries and abundant in South America, and it is easily collected on beaches without any environmental damage due to its occurrence/presence in the tropical waters of Brazil. It shows potential for the recovery of heavy metals from liquid effluents due to its physicochemical characteristics, apart from its low cost and high capacity to accumulate heavy metals when compared to ion-exchange resins and other adsorbent materials (Padilha et al. 2005).

The main polysaccharide in Sargassum seaweed is alginic acid, a polymer containing $\beta-1,4$ manuronic acid (M) associated to $\alpha-1,4$ guluronic acid $(G)$. The $M / G$ content in different brown seaweeds may vary under different environmental conditions and with different species, with both monomers able to accumulate heavy metals.

Literature presents few examples of the continuous application of biosorption, most of which are focused on surveys on operational parameters for selected systems. Volesky et al. (2003) tested a fixed-bed column reactor, filled with Sargassum filipendula, for the recovery of ionic lead, emphasizing the desorption of metal and the hydraulic conditions of the continuous system.

Seaweed Sargassum sp. biomass was used in the recovery of ionic copper from highly concentrated solutions simulating effluents from semiconductor production. The continuous system used contained four column reactors filled with the biomass of Sargassum sp. and showed high operational stability. Biomass of Sargassum sp. in the reactors was gradually saturated from the bottom to the top of each column reactor. The biomass of Sargassum sp. in the first column was saturated first, followed by a gradual saturation of the remaining columns due to the preconcentration caused by the biomass in the first column. The biomass of Sargassum in the bioreactors completely biosorbed the ionic copper contained in $63 \mathrm{~L}$ of copper sulphate solution, $72 \mathrm{~L}$ of copper chloride solution and $72 \mathrm{~L}$ of copper nitrate solution, all the solutions containing copper at $500 \mathrm{mg} / \mathrm{L}$. Effluents produced after biosorption presented copper concentrations less than $0.5 \mathrm{mg} / \mathrm{L}$ (Padilha et al. 2005).

The zinc biosorptive capacity of the brown seaweed Sargassum sp. (Phaeophyceae) was studied in the presence or absence of competing calcium ions, using a continuous system with tubular fixed-bed reactors (de França et al. 2002). In order to detect the effect of calcium on zinc biosorption, a $130 \mathrm{mg} / \mathrm{L}$ zinc solution was used, and calcium was added at $50-340 \mathrm{mg} / \mathrm{L}$. The potential zinc biosorptive capacity of the biomass was markedly influenced by the presence of ionic calcium. Zinc sorption decreased with increasing calcium concentrations, as expressed by zinc uptake rates. Calcium was effectively recovered only during the initial stages of the process, as expressed by the decrease in its uptake rates. Calcium uptake rates were also much higher than zinc uptake rates, indicating that calcium was preferentially recovered when compared to zinc.

Biosorption of $\mathrm{Pb}$ (II) and $\mathrm{Cu}$ (II) ions in single component and binary systems was studied using activated sludge in continuous-flow stirred reactors. Because of the low adsorption capacity of the non-viable activated sludge especially in the case of $\mathrm{Pb}$ (II) ions, biosorption of the $\mathrm{Cu}$ (II) and $\mathrm{Pb}(\mathrm{II})$ ions from the binary mixtures was carried out by using the resting cells. The biosorption data fitted better with the Freundlich adsorption isotherm model. Using a mathematical model based on continuous system mass balance for the liquid phase and batch system mass balance for the solid phase, the forward rate constants for biosorption of $\mathrm{Pb}$ (II) and $\mathrm{Cu}(\mathrm{II})$ ions were 0.793 and 0.242 ( $\mathrm{mmol} / \mathrm{min})$, respectively (Sag et al. 2003).

This research aimed to study the biosorption of lead by Sargassum filipendula in batch and continuous systems, obtaining equilibrium parameters in a static system to aid in the dynamic operation of bioreactors for the treatment of ionic lead in high concentrations.

\section{MATERIALS AND METHODS}

\section{Seaweed}

Sargassum filipendula (Phaeophyceae, Cyclosporeae, Fucales, Sargassaceae) was the biosorbent material. The biomass was obtained from the Northeastern coast of Brazil by the Brazilian company Assessa. This biomass was selected due to the results obtained in previous experiments (Cruz et al. 2004; Padilha et al. 2005).

\section{Preparation of the biomass for the experiments}

S. filipendula was washed with distilled water and ovendried at $70^{\circ} \mathrm{C}$ for $24 \mathrm{hrs}$. It was then sub-sampled from $1 \mathrm{~kg}$ of biomass, without being cut into pieces. Standard sampling techniques were used.

\section{Batch biosorption experiments for the selection of the optimum working $\mathrm{pH}$}

To investigate the optimum $\mathrm{pH}$ for the biosorption of lead by $S$. filipendula, $\mathrm{pH}$ values of lead nitrate solutions $(0.23 \pm$ $0.01 \mathrm{mmol} / \mathrm{L})$ were adjusted to $4.0,4.5$ and 5.0. These tests were performed in the absence of the biomass and with the addition of $S$. filipendula $(2.0 \mathrm{~g} / \mathrm{L})$. The $\mathrm{pH}$ was monitored before and after the equilibrium, to differentiate chemical precipitation and biosorption. Experiments were performed 
Table 1. Biosorption and chemical precipitation of lead at different $\mathrm{pH}$ values.

\begin{tabular}{|c|c|c|c|}
\hline & \multicolumn{3}{|c|}{$\mathrm{Pb}(\mathrm{II})(\mathrm{mmol} / \mathrm{L})^{\star}$} \\
\hline & pH 4.0 & $\mathrm{pH} 4.5$ & pH 5.0 \\
\hline Chemical precipitation (blank) & $0.23 \pm 0.01$ & $0.21 \pm 0.01$ & $0.16 \pm 0.01$ \\
\hline Biosorption & 0.002 & 0.004 & 0.005 \\
\hline
\end{tabular}

*Standard deviations were not reported, in some cases, due to their negligible values.

Initial lead concentration: $0.23 \pm 0.01 \mathrm{mmol} / \mathrm{L}$.

in a shaker, at $150 \mathrm{rpm}$ and $30 \pm 1^{\circ} \mathrm{C}$. This temperature was selected because it corresponds to the average temperature of the conventional treatment plants and no changes in lead biosorption were observed between $25^{\circ} \mathrm{C}$ and $55^{\circ} \mathrm{C}$, by the same biological system (Martins et al. 2006). After six hrs, the solutions were filtered through a $0.47 \mu \mathrm{m}$ Millipore membrane, for the quantification of lead by AA spectrometry. Each experiment was performed four times and average results were reported.

\section{Isotherms under optimized $\mathrm{pH}$ conditions}

In these experiments, $50 \mathrm{~mL}$ of lead nitrate in the concentrations of $0.03 \pm 0.001$ to $3.27 \pm 0.04 \mathrm{mmol} / \mathrm{L}$ at $\mathrm{pH}$ 4.0 were incubated in a shaker for $24 \mathrm{hrs}$ at $30 \pm 1^{\circ} \mathrm{C}$, for each of the tested biomass concentrations, 0.5, 1.0 and 2.0 $\mathrm{g} / \mathrm{L}$. After the incubation in the shaker, the samples were filtered and quantified by AA spectrometry. The experiments were performed four times.

The lead uptake (Q) was calculated by the simple concentration difference method. The initial concentration, $\mathrm{C}_{0}(\mathrm{mg} / \mathrm{L})$, and the metal concentration at any time, $\mathrm{C}_{\mathrm{t}}$ $(\mathrm{mg} / \mathrm{L})$, were determined. Metal uptake Q (mmol lead/g $S$. filipendula) was calculated from the mass balance (1):

$$
Q=\frac{\left(C_{0}-C_{t}\right)}{w \cdot 1000}
$$

where $\mathrm{V}$ is the volume of solution $(\mathrm{mL})$ and $\mathrm{w}$ the mass of sorbent $(\mathrm{g})$.

\section{Modeling equilibrium based on Langmuir and Freundlich equations}

The obtained experimental data were fitted to Langmuir and Freundlich equations, which are the most widely used in biosorption (Cossich et al. 2002; Cruz et al. 2004). The Langmuir model assumes the form (2):

$$
\mathrm{Q}_{e}=\frac{\mathrm{Q}_{0} \mathrm{~K}_{L} \mathrm{C}_{e}}{1+\mathrm{K}_{L} \mathrm{C}_{e}}
$$

where $\mathrm{Q}_{0}(\mathrm{mmol} / \mathrm{g})$ is the maximum amount of metal ion per unit weight of algae to form a complete monolayer on the surface. $\mathrm{C}_{\mathrm{e}}(\mathrm{mmol} / \mathrm{L})$ corresponds to the equilibrium concentration and $\mathrm{K}_{\mathrm{L}}(\mathrm{L} / \mathrm{mmol})$ is the equilibrium adsorption constant, related to the affinity of the binding sites. $\mathrm{Q}_{0}$ represents the limiting adsorption capacity for adsorption performance (Aksu, 2001). Parameters can be determined from a linearized form of (2), represented by (3):

$$
\frac{\mathrm{C}_{\mathrm{e}}}{\mathrm{Q}_{\mathrm{e}}}=\frac{1}{\mathrm{Q}_{0} \mathrm{~K}_{\mathrm{L}}}+\frac{1}{\mathrm{Q}_{0}} \mathrm{Ce}_{\mathrm{e}}
$$

A plot of $\left(\mathrm{C}_{\mathrm{e}} / \mathrm{Q}_{\mathrm{e}}\right)$ versus $\mathrm{C}_{\mathrm{e}}$, gives a straight line of a $1 / \mathrm{Q}_{0}$ slope and a $1 /\left(\mathrm{Q}_{0} \mathrm{~K}_{\mathrm{L}}\right)$ intercept. On the other hand, the Freundlich equation is given by (4):

$$
\mathrm{Q}_{\mathrm{e}}=\mathrm{K}_{\mathrm{F}}\left(\mathrm{C}_{\mathrm{e}}\right)^{1 / \mathrm{n}}
$$

where $\mathrm{K}_{\mathrm{F}}$ and $\mathrm{n}$ are the Freundlich constants, indicating the adsorption capacity and adsorption intensity, respectively. The derivation of $\mathrm{K}_{\mathrm{F}}$ and $1 / \mathrm{n}$, can be linearized in logarithmic form (5):

$$
\log \mathrm{Q}_{\mathrm{e}}=\log \mathrm{K}_{\mathrm{F}}+(1 / \mathrm{n}) \log \mathrm{C}_{\mathrm{e}}
$$

\section{Kinetic experiments and modeling}

For the kinetic study of the biosorption of lead by $S$. filipendula, the concentration of ionic lead was monitored throughout the time (up to $45 \mathrm{~min}$ ), using a solution containing lead in the concentration of $0.23 \pm 0.01 \mathrm{mmol} / \mathrm{L}$, at $\mathrm{pH} 4.0$.

\section{Continuous experiments}

The continuous system contained four serial fixed-bed column reactors, $70.0 \mathrm{~cm}$ high with a $7.0 \mathrm{~cm}$ internal diameter; each reactor was filled with dried S. filipendula (120 g biomass per column). The effluent from each column became the influent for the next reactor in the series. This was done using a peristaltic pump connected to the bottom of the first column $(50 \mathrm{~mL} / \mathrm{min})$.

Five experiments were conducted in a continuous system, each of them at a distinct concentration: $0.24 \pm 0.02,0.48 \pm$ $0.05,1.21 \pm 0.10,2.42 \pm 0.23$ and $4.83 \pm 0.62 \mathrm{mmol} / \mathrm{L}$ ionic lead, at $\mathrm{pH}$ 4.0. Samples were collected from the top of each column at three-hour intervals, filtered, acidified and quantified in relation to the lead content. Each experiment was conducted during $60 \mathrm{hrs}$ and repeated four times under the same conditions; therefore, the reported values constitute the average lead determinations for each 
Table 2. Langmuir and Freundlich lead adsorption constants on Sargassum filipendula.

\begin{tabular}{|c|c|c|c|c|c|c|}
\hline \multirow{2}{*}{$\begin{array}{c}\text { Biomass } \\
(\mathbf{g} / \mathbf{L})\end{array}$} & \multicolumn{3}{|c|}{ Langmuir constants } & \multicolumn{3}{c|}{ Freundlich constants } \\
\cline { 2 - 7 } & $\begin{array}{c}\mathbf{Q}_{\mathbf{0}} \\
\mathbf{m g} / \mathbf{g})\end{array}$ & $\begin{array}{c}\mathbf{K}_{\mathbf{L}} \\
\mathbf{( L / g} \text { mol) }\end{array}$ & $\mathbf{R}^{\mathbf{2}}$ & $\mathbf{n}$ & $\mathbf{K}_{\mathbf{F}}$ & $\mathbf{R}^{\mathbf{2}}$ \\
\hline 0.5 & $1.18 \pm 0.02$ & $23.7 \pm 6.9$ & 0.9992 & $2.66 \pm 0.01$ & $4.72 \pm 0.02$ & 0.9086 \\
\hline 1.0 & $1.20 \pm 0.05$ & $20.2 \pm 7.0$ & 0.9934 & $2.06 \pm 0.01$ & $4.06 \pm 0.02$ & 0.6349 \\
\hline 2.0 & $1.35 \pm 0.07$ & $20.2 \pm 6.4$ & 0.9894 & $1.79 \pm 0.01$ & $4.00 \pm 0.01$ & 0.7520 \\
\hline
\end{tabular}

experimental condition. Standard deviations were calculated to estimate the dispersion levels of the individual values in relation to a calculated mean value.

Through each breakthrough curve that was obtained, it was possible to evaluate the performance of the continuous system, thus identifying the most adequate operational conditions.

\section{RESULTS AND DISCUSSION}

\section{Batch biosorption experiments for the selection of the optimum working $\mathrm{pH}$}

The biosorption of lead by S. filipendula at different $\mathrm{pH}$ values is presented in Table 1 .

The presented results indicate that in the absence of the biomass a chemical precipitation occurred since the lead began to precipitate after $\mathrm{pH} 4.5$. At $\mathrm{pH}$ 5.0, however, the chemical precipitation was the most pronounced in relation to the values at $\mathrm{pH} 4.0$ and 4.5 .

In the experiments in which the biomass was added, the equilibrium concentrations of lead were considerably lower in comparison to the chemical precipitation, which indicates a great contribution of the biosorption in relation to the chemical precipitation.

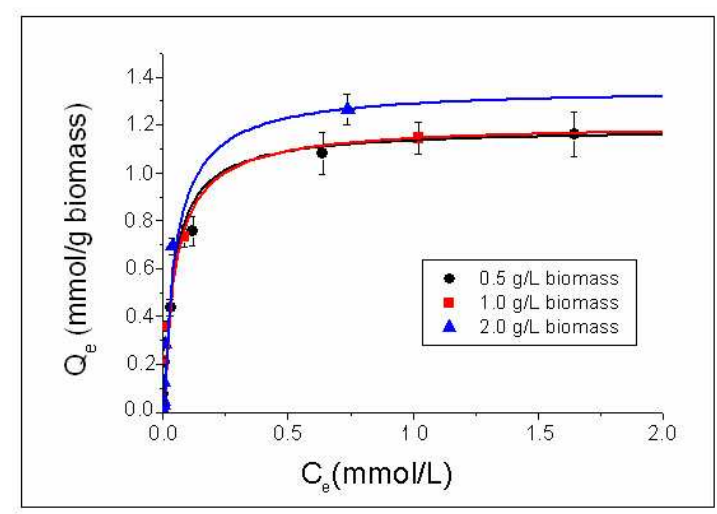

Figure 1. Lead biosorption isotherms using Sargassum filipendula $\left(30^{\circ} \mathrm{C}, 150 \mathrm{rpm}\right.$ shaking rate). Discrete points: experimental data; full and dotted lines: Langmuir isotherm model.

The equilibrium concentrations ranged from 0.002 to 0.005 $\mathrm{mmol} / \mathrm{L}$, crescent in relation to the $\mathrm{pH}$ increase. At $\mathrm{pH}$ lower than 3.0, lead removal was inhibited possibly as result of a competition between hydrogen and lead ions, with an apparent preponderance of hydrogen ions. For this reason those results are not reported in Table 1. With an increase in $\mathrm{pH}$, the negative charge density on the biomass increases due to deprotonation of the metal binding sites, thus increasing metal biosorption.

The $\mathrm{pH}$ is one of the most important parameters of biosorption (Kapoor et al. 1999; Aksu, 2001) and, regarding Sargassum sp., its high content of ionizable groups (carboxyl groups), makes it very liable to be influenced by the $\mathrm{pH}$ of the medium. For Sargassum sp., carboxyl groups are chiefly responsible for binding metallic ions.

However other functional groups may contribute to the process, such as the sulfonate and amine groups.

The higher the $\mathrm{pH}$ value, the higher the dissociation since free sites for the binding of lead can be produced, however, the majority of heavy metals precipitate at $\mathrm{pH}$ values over 5.5 .

Ho (2005), using tree fern, showed that $\mathrm{pH}$ values in the range of 4.0 to 7.0 were adequate for lead binding, of which $\mathrm{pH} 4.9$ is the optimum value for the biosorbent.

These values are contrary to those obtained in the present research, the aim of which was the preponderance of chemical precipitation.

Associating the fact that at $\mathrm{pH} 4.0$ no chemical precipitation occurred to the fact that the lowest equilibrium concentration was obtained, this value was considered ideal for subsequent experiments.

\section{Isotherms in optimized $\mathrm{pH}$ conditions}

The results that were obtained through batch processing are presented in Figure 1. Evaluating the results presented in Figure 1, it can be concluded that for the concentrations in the range of $0.03 \pm 0.001$ to $3.27 \pm 0.04 \mathrm{mmol} / \mathrm{L}$, under the conditions of the experiments, a biomass concentration equal to $2.0 \mathrm{~g} / \mathrm{L}$ was the most interesting since it generated the lowest equilibrium concentrations.

An analysis of Figure 1 can be carried out not only considering the obtained equilibrium concentrations for the different lead solutions, but also evaluating its uptake capacity. 
For all biomass concentrations tested, the uptake capacities increases with the equilibrium concentration, up to 0.5 $\mathrm{mmol} / \mathrm{L}$, and then tend to a constant value. Similarly, the value that was measured for the maximum uptake capacity of the biomass has not demonstrated a significant variation among the values of which the mean value was $1.2 \mathrm{mmol}$ $\mathrm{Pb} / \mathrm{g}$ S. filipendula.

The main difference that was observed relates to the curve profiles. In the $0.5 \mathrm{~g} / \mathrm{L}$ biomass concentration, the experimental stabilization of the lead uptake by the biomass can be verified probably due to the saturation of the binding sites. However, with biomass concentrations of 1.0 and 2.0 $\mathrm{g} / \mathrm{L}$, this tendency to stabilize was not observed because these biomass concentrations could still lead to a uptake of additional ionic lead if higher lead concentrations were used.

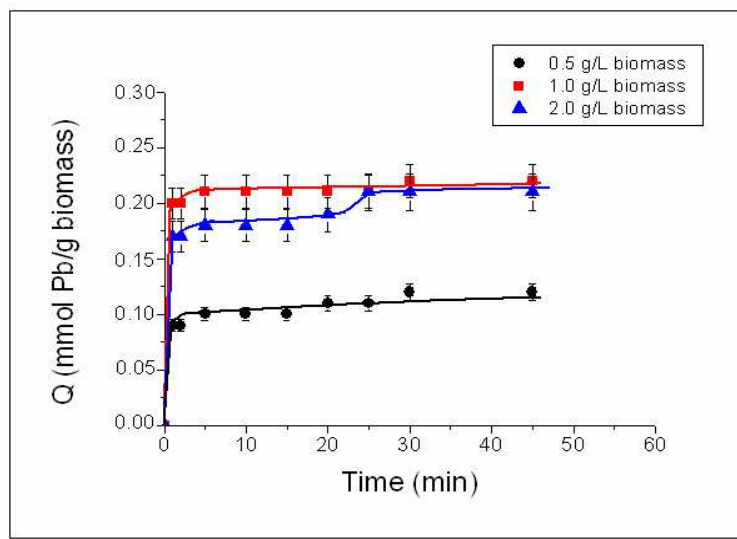

Figure 2. Kinetic behaviour of biosorption of lead by $S$. filipendula (Initial concentration of $\mathrm{Pb}$ (II) $=0.23 \pm 0.01$ $\mathrm{mmol} / \mathrm{L} ; \mathrm{T}=30 \circ \mathrm{C} ; \mathrm{pH}=4$; shaking rate $150 \mathrm{rpm}$ ).

Matheickal and Yuh (1999) reported that batch equilibrium experiments showed that the maximum adsorption of lead by chemically modified Durvillaea potatorum was 1.6 $\mathrm{mmol} / \mathrm{g}$ and $1.3 \mathrm{mmol} / \mathrm{g}$ for Ecklonia radiata, which is slightly higher than the maximum value obtained in this research in the batch system $(1.2 \mathrm{mmol} / \mathrm{g})$. Raize et al. (2004) reported the binding capacities for different cations, including lead to be between 1 and $1.2 \mathrm{mmol} \mathrm{metal} / \mathrm{g}$ on a dry weight basis.

\section{Modeling based on the Langmuir e Freundlich Equations}

Table 2 presents the results of Langmuir and Freundlich lead adsorption constants on Sargassum filipendula. It can be seen a good correlation between the values estimated by the Langmuir model and the experimental results (Figure 1). The maximum values for the experimental $Q$ were 1.16, 1.14 and $1.26 \mathrm{mmol} \mathrm{lead} / \mathrm{g}$ biomass, with $0.5,1.0$ and 2.0 $\mathrm{g} / \mathrm{L}$ of $S$. filipendula, respectively.

The values predicted by the model based on the Langmuir equation were $1.18,1.20$ and $1.35 \mathrm{mmol} / \mathrm{g}$, with the addition of $0.5,1.0$ e $2.0 \mathrm{~g} / \mathrm{L}$ of $S$. filipendula, respectively.
This corresponds to very small percent differences that are corroborated by the high coefficients of the obtained correlations.

From Table 2 it can be observed that the Freundlich isotherm did not fit the experimental data as good as the Langmuir model, which can be proved by the values of the corresponding constants and correlation coefficients.

The data in Table 2 indicate a low correlation between the experimental values and those estimated by the Freundlich model. The Freundlich model does not predict the surface saturation of the adsorbent after the formation of a monolayer on the metal.

The overall batch results indicate that the Langmuir isotherms best fitted the experimental data over the studied experimental range since they presented higher correlation coefficients in all of the biomass concentrations. The experimental data and the predicted profiles are in agreement in the entire range of $\mathrm{Ce}$ and the evaluated biomass concentrations. Jalali et al. (2002) confirmed that Sargassum hystrix, Sargassum natans and Padina pavonia removed lead efficiently from an aqueous solution, fitting Langmuir and Freundlich models and with an increasing uptake of the metal with increasing $\mathrm{pH}$ values.

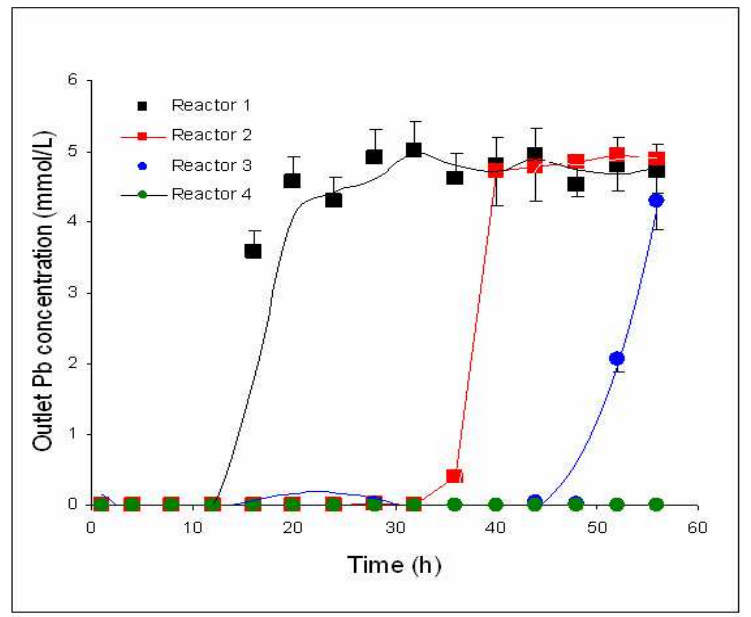

Figure 3. Breakthrough curves during the continuous biosorption of lead by S. filipendula. Reactors are $70.0 \mathrm{~cm}$ high and with a $7.0 \mathrm{~cm}$ internal diameter. Each reactor filled with $120 \mathrm{~g}$ biomass. $\mathrm{Pb}$ (II) feed concentration equal to $4.83 \mathrm{mmol} / \mathrm{L}$.

Table 3 presents a comparison of $\mathrm{Pb}(\mathrm{II})$ sorption capacities for some conventional and biological sorbents. Those results indicate that the biosorption capacity of Sargassum filipendula biomass is just comparable to the performance observed by the marine algae Durvillaea potatorum and Ecklonia radiata (Matheickal and Yu, 1999). The remaining conventional sorbents reported and other biological materials such as the fungus Rhizopus arrhizus and the bacteria Pseudomonas aeruginosa did not present uptake capacities comparable to the values obtained in the present work. 


\section{Kinetic experiments and modeling}

The results that were obtained from the kinetic study of biosorption is presented in Figure 2. They indicate an extremely rapid kinetic rate of $\mathrm{Pb}$ (II) removal in the first $\mathrm{min}$, and an approach to reach equilibrium in about $10 \mathrm{~min}$. Thus, in the present work, the kinetics of lead removal was not modeled.

Other literature reports that the biosorption of metallic elements by the biomass of the brown seaweed Sargassum $\mathrm{sp}$. is a rapid phenomenon; however, the time to reach equilibrium is not as short as that observed in the present work.

Jalali et al. (2002) reported that the biosorption of lead by eight types of marine algae rapidly occurred and that most of the adsorbed metal was bound in less than $30 \mathrm{~min}$. Sheng et al. (2004) observed for distinct seaweeds, among which Sargassum sp. and Padinasp., a 60-min equilibrium time for lead, with an accumulation of 0.61 to $1.16 \mathrm{mmol} / \mathrm{g}$ for Sargassum sp. and 0.63 to $1.25 \mathrm{mmol} / \mathrm{g}$ for Padina sp. Likewise, Keskinkan et al. (2004) reported that the biosorption of lead by the aquatic plant Ceratophyllum demersum presented equilibrium in $20 \mathrm{~min}$ with an accumulation of $0.21 \mathrm{mmol} / \mathrm{g}$.

Table 3. Comparison of $\mathrm{Pb}$ (II) biosorption capacities for conventional and biological sorbent materials.

\begin{tabular}{|c|c|c|}
\hline Sorbent material & $\begin{array}{c}Q_{0} \\
\left(\mathrm{mmol} \mathrm{g}^{-1}\right)\end{array}$ & Reference \\
\hline Australian natural zeolite & 0.08 & $\begin{array}{l}\text { Matheickal and Yu, } \\
\text { 1996a }\end{array}$ \\
\hline Powder activated carbon & 0.10 & $\begin{array}{l}\text { Matheickal and Yu, } \\
\text { 1996b }\end{array}$ \\
\hline $\begin{array}{l}\text { Granulated activated } \\
\text { carbon, F- } 400\end{array}$ & 0.15 & $\begin{array}{l}\text { Muraleedharan et al. } \\
1995\end{array}$ \\
\hline Rhizopus arrhizus & 0.50 & Volesky, 1990 \\
\hline Pseudomonas aeruginosa & 0.33 & Chang et al. 1997 \\
\hline Ecklonia radiata & 1.26 & $\begin{array}{l}\text { Matheickal and Yu, } \\
1999\end{array}$ \\
\hline Durvillaeapotatorum & 1.55 & $\begin{array}{l}\text { Matheickal and Yu, } \\
1999\end{array}$ \\
\hline Sargassumfilipendula & 1.35 & Present work \\
\hline
\end{tabular}

\section{Continuous experiments}

The experiments that were carried out in the continuous system, at lead concentrations varying between 50.0 and $500.0 \mathrm{mg} / \mathrm{L}$ in the effluent, presented the total uptake of lead, thus, not reported graphically. The results of the effluents containing lead in the concentration of 1,000 $\mathrm{mg} / \mathrm{L}(4.83 \mathrm{mmol} / \mathrm{L})$ are presented in Figure 3.

The breakthrough curves were obtained under optimized hydraulic operational conditions. The critical bed depth, residence time and flow rate were optimized in preliminary experiments in order to observe the Brazilian Legislation as established by the National Environmental Council (CONAMA, 1986).
Observing the curve of the first reactor of the continuous system, it can be verified that until $12 \mathrm{hrs}$ of operation, the first column removed the loaded lead with a $100 \%$ efficiency, which corresponds to the treatment of 36 liters of metal concentrated solution or $36 \mathrm{~g}$ of lead. During these $12 \mathrm{hrs}$ of operation the obtained loading patterns were observed as established by the Brazilian legislation (0.5 $\mathrm{mg} / \mathrm{L})$.

Subsequently, a residual concentration of lead began to increase substantially related to the gradual saturation of the binding sites on the surface of S. filipendula, until reaching a value near the loading concentration, indicating saturation.

The performance of the column is related to the length and width of the absorption zone, which is developed between the section that is saturated with metal and the one that contains free biosorbent. When this adsorbent zone or mass transferal reaches the highest part of the bed, the solute in the effluent begins to increase; then, the system initiates the rupture. This point, which is called the breakthrough point is to be the maximum allowable lead concentration $(0.5$ $\mathrm{mg} / \mathrm{L})$.

Column 1 saturated completely after $28 \mathrm{hrs}$ of continuous operation. From this point, at which the S. filipendula biomass was no longer able to remove the lead, it began to feed column 2.

In the curve corresponding to the second reactor of the continuous system, there was an effective treatment of 96 liters of effluent with a residual lead concentration of nearly zero. This value corresponds to $32 \mathrm{hrs}$ of continuous operation. A gradual increase of the residual lead concentration occurred reaching values that were approximately equal to the effluent of the first column. In the breakthrough curve related to the third column, it can be verified that, after feeding 144 liters of the solution, the residual lead concentration approached zero. This can be explained by the fact that the solution entering this column comes from the second column and therefore takes more time to saturate; thus, it is able to purify a larger volume.

In the fourth column of the continuous system, it can be verified that after the treatment of 168 liters of concentrated ionic lead effluent with a100\% efficiency, the operation of the continuous system was interrupted.

The cumulative results of the continuous system demonstrate that all of the influent lead loaded into to the system was treated, that is, all of the lead was removed by the biomass inside the fixed-bed reactors. Through a global evaluation, it can be concluded that $168 \mathrm{~g}$ of lead was accumulated by the biomass.

This reactor is still far from saturation with lead, which can be observed by its breakthrough curve. The system could still operate for some more hrs since the lead concentration that comes out of the fourth bioreactor, after $56 \mathrm{hrs}$ of operation, is zero. The system treated all of the loaded 
solution and the Sargassum filipendula biomass presented, at the least, an uptake capacity of the metallic element in the order of $350 \mathrm{mg} \mathrm{lead} / \mathrm{g} \mathrm{S}$. filipendula $(1.70 \mathrm{mmol} / \mathrm{g})$. It must be emphasized that the capacity of the biomass of accumulating lead can be even higher than aforementioned since the fourth reactor of the system still shows potential for higher accumulation rates of the metal.

In subsequent experiments, the biomass may be treated so as to allow the recycling of lead (Jeon et al. 2005) accumulated in its structure. Then, the first reactor of the continuous system will return to the system in the last position (as the fourth reactor) while the global system still operates. The other bioreactors may undergo similar treatment, and so continue until the biomass loses its capacity to remove the metal and needs to be substituted, as conventionally done with ion-exchange resins.

\section{CONCLUDING REMARKS}

The $\mathrm{pH}$ value that was selected for the experiments on the biosorption of lead by $S$. filipendula was $\mathrm{pH} 4.0$ since it combined the best characteristics for the lowest chemical precipitation and the highest biosorption. The Langmuir isotherms represented the batch removal system well, achieving a maximum uptake rate of the metallic element of $243 \pm 0.04$ to $277.7 \pm 0.02$. The rapid kinetics turns the process attractive for the use in fixed-bed bioreactors, which can be confirmed by the batch experiments in which the uptake time, until reaching equilibrium, was approximately $30 \mathrm{~min}$, which allowed for a long-term operation of the continuous system. The experimental data that were modeled into kinetic equations indicate secondorder kinetics during the biosorption. The continuous system recovered a high quantity of lead, $168 \mathrm{~g}$, equivalent to that which can be observed in relation to conventional chemical treatments for the chemical precipitation of the element. The high uptake rates of the soluble metallic element indicate the potential of the macroalga $S$. Filipendula as a lead concentrator and further recycling.

\section{REFERENCES}

AKSU, Z. Equilibrium and kinetic modeling of cadmium(II) biosorption by $C$. vulgarisin a batch system: effect of temperature. Separation and Purification Technology, January 2001, vol. 21, no. 3, p. 285-294.

CHANG, Jo-Shu; LAW, Robin and CHANG, ChungCheng. Biosorption of lead, copper and cadmium by biomass of Pseudomonas aeruginosa PU-21. Water Research, July 1997, vol. 31, no. 7, p. 1651-1658.

Conselho Nacional do Meio Ambiente, CONAMA. CONAMA Law 20. (18 ${ }^{\text {th }}$ June, 1986) 1986,20 p.

COSSICH, Eneida Sala; TAVARES, Célia Regina Granhen and RAVAGNANI, Teresa Massako Kakuta. Biosorption of chromium(III) by Sargassum sp. biomass. Electronic
Journal of Biotechnology [online] 15 August 2002, vol. 5, no. 2 [16 December 2006] Available from internet: http://www.ejbiotechnology.info/content/vol5/issue2/full/4/ index.html. ISSN 0717-3458.

CRUZ, Claudio C.V.; DA COSTA, Antonio Carlos A.; HENRIQUES, Cristiane Assumpçäo and LUNA, Aderval S. Kinetic modeling and equilibrium studies during cadmium biosorption by dead Sargassum sp. biomass. Bioresource Technology, February 2004, vol. 91, no. 3, p. 249-257.

DE FRANÇA, Francisca Pessôa; TAVARES, Ana Paula and DA COSTA, Antonio Carlos Augusto. Calcium interference with continuous biosorption of zinc by Sargassum sp. (Phaeophyceae) in tubular laboratory reactors. Bioresource Technology, June 2002, vol. 83, no. 2, p. 159-163.

HO, Yuh-Shan. Effect of $\mathrm{pH}$ on lead removal from water using tree fern as the sorbent. Bioresource Technology, July 2005, vol. 96 , no. 11 , p. 1292-1296.

JALALI, R.; GHAFOURIAN, H.; ASEF, Y.; DAVARPANAH, S.J. and SEPEHR, S. Removal and recovery of lead using nonliving biomass of marine algae. Journal of Hazardous Materials, June 2002, vol. 92, no. 3, p. 253-262.

JEON, Choong; YOO, Young Je and HOELL, Wolfgang H. Environmental effects and desorption characteristics on heavy metal removal using carboxylatedalginic acid. Bioresource Technology, January 2005, vol. 96, no. 1, p. 15-19.

KAPOOR, Anoop; VIRARAGHAVAN, Thiruvenkatachari and CULLIMORE, D. Roy. Removal of heavy metals using the fungus Aspergillus niger. Bioresource Technology, October 1999, vol. 70, no. 1, p. 95-104.

KESKINKAN, O.; GOKSU, M.Z.L.; BASIBUYUK, M. and FORSTER, C.F. Heavy metal adsorption properties of a submerged aquatic plant (Ceratophyllum demersum). Bioresource Technology, April 2004, vol. 92, no. 2, p. $197-$ 200.

MARTINS, Bruno L.; CRUZ, Claudio C.V.; LUNA, Aderval S. and HENRIQUES, Cristiane A. Sorption and desorption of $\mathrm{Pb}^{2+}$ ions by dead Sargassum sp. biomass. Biochemical Engineering Journal, January 2006, vol. 27, no. 3, p. 310-314.

MATHEICKAL, Jose T. and YU, Qiming. Biosorption of lead from aqueous solution by marine algae Ecklonia radiata. Water Science and Technology, 1996a, vol. 34, no. 9, p. 1-7.

MATHEICKAL, Jose T. and YU, Qiming. Biosorption of lead from aqueous solution by macro-fungi Phellinusbadius. In: Proceedings of the $10^{\text {th }}$ National 
Convention of Royal Australian Chemical Institute. $\left(27^{\text {th }}\right.$ September, 1996, Adelaide, Australia). 1996b, p. 04.

MATHEICKAL, Jose T. and YU, Qiming. Biosorption of lead(II) and copper(II) from aqueous solutions by pretreated biomass of Australian marine algae. Bioresource Technology, September 1999, vol. 69, no. 3, p. 223-229.

MURALEEDHARAN, T.R.; IYENGAR, L. and VENKOBACHAR, C. Screening of tropical wood-rotting mushrooms for copper biosorption. Applied and Environmental Microbiology, September 1995, vol. 61, no. 9, p. 3507-3508.

PADILHA, Flávia Pinto; DE FRANÇA, Francisca Pessôa and DA COSTA, Antonio Carlos Augusto. The use of waste biomass of Sargassum sp. for the biosorption of copper from simulated semiconductor effluents. Bioresource Technology, September 2005, vol. 96, no. 13, p. 1511-1517.

RAIZE, Ofer; ARGAMAN, Yerachmiel and YANNAI, Shmuel. Mechanisms of biosorption of different heavy metals by brown marine macroalgae. Biotechnology and Bioengineering, August 2004, vol. 87, no. 4, p. 451-458.

SAG, Yesim; TATAR, Berya and KUTSAL, Tülin. Biosorption of $\mathrm{Pb}$ (II) and $\mathrm{Cu}$ (II) by activated sludge in batch and continuous-flow stirred reactors. Bioresource Technology, March 2003, vol. 87, no. 1, p. 27-33.

SHENG, Ping Xin; TING, Yen-Peng; CHEN, J. Paul and HONG, Liang. Sorption of lead, copper, cadmium, zinc, and nickel by marine algal biomass: characterization of biosorptive capacity and investigation of mechanisms. Journal of Colloid and Interface Science, July 2004, vol. 275, no. 1, p. 131-141.

VOLESKY, Bohumil. Biosorption and biosorbents. In: VOLESKY, Bohumil ed. Biosorption of Heavy Metals. Boca Raton, FL, CRC Press, 1990, p. 3-6.

VOLESKY, B.; WEBER, J. and PARK, J.M. Continuousflow metal biosorption in a regenerable Sargassum column. Water Research, January 2003, vol. 37, no. 2, p. 297-306. 